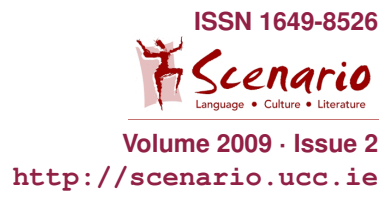

Review

\title{
Thomas Müller (2008). Dramapädagogik und Deutsch als Fremdsprache. Eine Bestandsaufnahme. Saarbrücken. VDM Verlag
}

\section{Bettina Matthias}

Over the past decade, theater-and drama-related activities in the foreign language classroom have enjoyed increasing popularity. More and more foreign language programs have added theater-based literature classes to their course offerings, and theater- and drama-pedagogical workshops, offered through organizations such as the Goethe Institute or the Alliance Française, have helped teachers and students access this creative approach to foreign language instruction. Publications based on "eher subjektive Eindrücke und Erfahrungen" (9) abound; but, so far, a synthesizing account of these methods' place in foreign language pedagogy, their contributions to didactics, and a systematic typology of drama-pedagogical methods and exercises has been lacking.

Thomas Müller's recently published book Dramapädagogik und Deutsch als Fremdsprache. Eine Bestandsaufnahme. [Saarbrücken: VDM Verlag Dr. Müller, 2008. 145pp.] aims to supply such a systematic account. Drawing on his experience as an actor and as a DAAD Lektor in Dublin, Müller offers a comprehensive introduction to and overview of existing theories on the topic of theater- and drama-in-education, and he devotes most of his book to locating "drama pedagogy" (drama-in-education) within existing foreign language paradigms, most prominently the communicative approach.

Müller begins his project by differentiating between theater-in-education (TiE) and drama-in-education (DiE): "Im Falle von TiE spielen andere Theater, worüber im Unterricht reflektiert wird. DiE impliziert jedoch, dass die Lernenden selbst szenisch oder anderweitig 'dramatisch' aktiv werden" $(22 / 23)$. Considering the general movement toward communicative language teaching in the Western world, Müller pleads for a broader and more educated exploration of the opportunities afforded by drama-pedagogical methods to the communicative foreign language classroom. To develop intercultural "Kommunikativ[e] Kompetenz" (99), learners have to understand language as a complex system of verbal and non-verbal, that is physical, expressions, as well as a means for intercultural negotiation in which the language user's personal (hi)story, body, imagination, and aesthetic sensibilities are activated and challenged. Müller devotes a long chapter to explaining how DiE speaks to all of these areas. As an interactive method that creates real-life situations in a safe environment, DiE offers opportunities for using and experimenting with 
the FL and inevitably promotes cultural and intercultural negotiations between users that also results in differentiated learning.

Given the obvious benefits of DiE, one could wonder why more teachers have not already included this method in their teaching. Müller offers an explanation for this, and he also takes into account criticism that has been voiced towards DiE. In order to use DiE successfully, teachers and learners must be willing to change their traditional attitude towards a classroom in which teachers guide and students follow. Instead, they become partners in their exploration of a topic. Students thus take greater responsibility for their own learning and the use of their time in class, while teachers have to become coaches, facilitators, and moderators of processes (e.g. as "Teacher in Role"/ TiR, a technique going back to Dorothy Heathcote). However, whether students are ready or willing to assume this responsibility for "autonom[es Lernen]" (97) is an open question and certainly varies from culture to culture. Furthermore, the freedom afforded by creative approaches such as DiE also presents a risk: "Auch für dp [dramapädagogischen] Unterricht gilt, dass die Gefahr der Freiheit darin besteht, dass man sie nicht zu nutzen weiß, keine eigene Struktur findet un in der Vielfalt ertrinkt" (95).

It is this problem that Müller really wants to target with his book. He calls for the inclusion of drama-pedagogical methods in a foreign language teacher's training and demands both that teachers educate themselves as actors, directors, and dramaturges, and that drama-pedagogy practitioners offer more comprehensive and systematic (written) contributions to the existing body of literature. Müller himself presents a number of drama-pedagogical activities and methods ("Inszenierungstechniken", 49ff.) such as pantomimes, "Standbilder" (the still image, or tableau), doubling, improvisation, play-back theater, simulation and more. In the last section of his book, he offers possible approaches to a systematic typology of methods and activities.

While Müller's book does not really offer new insights or impulses in and for drama-pedagogical teaching, it is a well-researched and thorough investigation of the current state of drama pedagogy, its place within the communicative approach and its potential for further exploration. Given its merits, it is a pity that Müller's style as well as his "strategy of delayed fulfillment" make the book a difficult read. Written in German, this book is a good - and sad - example of convoluted academic writing. Nouns dominate much of his writing, hypotaxis is the syntax of choice, the passive voice its "impersonal marker", and Müller's preference for foreign words such as "Narration" or "Metaphorizität" (40) discourages a friendly reception of his interesting ideas. Granted, many of these terms are taken from other scholars' writings - but an author has the choice of using these or not. The worst example of such loaned "wisdom" is the chapter "Narrativität" $(2.3 .2,35 \mathrm{ff}$.) in which Müller relies on Inge Schwerdtfeger's heavily abstract language. If play is the mode in which learning and negotiation can take place most successfully as Müller suggests in his opening paragraph-, he does not make it easy for his readers to "play along." Furthermore, his decision to offer an integrated 
survey of existing scholarly literature and practical suggestions for drama pedagogy practitioners often leads to frustration: announcements such as "Wie sieht nun die dp [dramapädagogische] Arbeit konkret aus?" (48) or the chapter heading "Systematik von Übungsformen" (111) make the reader expect concrete suggestions - which Müllers offers only after surveying more of the existing literature. These references are certainly important, but it would have been a nice gesture towards his readers to give them what they expect and offer the survey of alternative systems or approaches after presenting his own.

Finally, even though Müller is a native speaker, the book contains a rather annoying number of grammatical errors (wrong adjective endings, wrong case endings for plural forms, wrong subject-verb agreement) and missing commas, especially in the last third of the book. Given the length of some of Müller's sentences, it is easy to lose track of connections between nouns and adjectives, or subjects and verbs. More diligent editing would have been a plus.

All in all, Müller's book offers an interesting account of the state of dramapedagogical methods in the context of foreign language pedagogy and charts the territory for those of us who are invested in this method. Less lingo and more concrete examples and suggestions would have made the book a more approachable and pleasant read; but for those who need a general introduction to what can be done with drama pedagogy, it is a good choice.

\section{Bibliography}

Thomas Müller. (2008): Dramapädagogik und Deutsch als Fremdsprache. Eine Bestandsaufnahme. Saarbrücken: VDM Verlag. 